\title{
Pengaruh Variabel Peningkatan Produktivitas, Penguasaan Teknologi Baru dan Pelatihan Terhadap Pengendalian Mutu Terpadu Karyawan Pada Industri Tekstil dan Garmen di Surakarta
}

\section{Effect of Improved Productivity Variable, New Technological Mastery and Integrated Quality Control Training of Employees in Textile and Garment Industry in Surakarta}

\author{
Ahmad Darmawi ${ }^{1,2}$, Darsono ${ }^{3}$, Drajat T. Kartono ${ }^{3}$, Sapja Anantanyu ${ }^{3}$ \\ Akademi Komunitas Industri Tekstil dan Produk Tekstil(AK-Tekstil)Surakarta \\ Jl. Ki Hajar Dewantara, Jebres, Sølo ${ }^{l}$ \\ Pusat Pendidikan dan Pelatihan Industri Sekretariat Jenderal \\ Sekolah Menengah Kejuruan - SMTI Pontianak Jl. Sulawesi Dalam No.31. Pontianak ${ }^{2}$ \\ Universitas Sebelas Maret Surakarta \\ Jl. Ir. Sutami No.36A. Kota Surakarta ${ }^{3}$ \\ E-mail: darmawi@kemenperin.go.id \\ Diterima: 07112017 \\ pisetujiri: 2504 2018 \\ Dipublikasi: 30052018 \\ Integrated Quality Control requires the participation of all divisions within the company, such as marketing, design, \\ manufacturing. Laboratopy examination. As an integrated process that focuses on customers and beneficiaries, it \\ simultaneously aims to protect and enhance the satisfaction of all stakeholders. Employee development does cost a \\ lot, but it is a long-term investment for the company in personnel. Because skilled and skilled employees will be able \\ to work more efficiently, effectively, mastage of raw materials, and less machine wear, better results will increase \\ the company's competitiveness. The purpose of this research is (a) to know the level of Employee Productivity \\ (TPK), (b) Employee Training (PK) and (c) Latest Technology Development (PTT) whether the positive effect on \\ Integrated Employee Quality Control (PMTK). This research use Survey research method by using quantitative \\ approach. The results obtained the employee Productivity Level positive effect on Integrated Quality Control \\ Employees with 0,972 standardized coefficients. Employee Training has a positive effect on Integrated Employee \\ Quality Control with anstandardized coefficient of 0.164. Latest Technology Development positively influences to \\ Integrated Quality Control Employee with a coefficient of standardized 0,114.
}

Keywords: Productivity, Training, Technology Development, Integrated Quality Control.

\begin{abstract}
Abstrak
Pengendalian Mutu Terpadu membutuhkan partisipasi dari semua divisi dalam perusahaan, seperti divisi pemasaran,disain, pabrikasi. Pemeriksaan laboratorium. Sebagai sebuah proses yang terintegrasi dengan berfokus pada pelanggan dan penerima manfaat, namun secara bersamaan mempunyai tujuan untuk melindungi dan meningkatkan kepuasan semua pemangku kepentingan. Pengembangan karyawan memang membutuhkan biaya cukup besar, tetapi biaya ini merupakan investasi jangka panjang bagi perusahaan di bidang personalia. Karena karyawan yang cakap dan trampil akan dapat bekerja lebih efisien, efektif, pemborosan bahan baku, dan ausnya mesin berkurang, hasil kerjanya lebih baik maka daya saing perusahaan akan semakin besar. Tujuan dari
\end{abstract}


Ahmad Darmawi / Jurnal Manajemen Industri dan Logistik - Vol. 02 No. 01, Mei 2018

penelitian ini adalah (a) mengetahui Tingkat Produktivitas Karyawan (TPK), (b) Pelatihan Karyawan (PK) dan (c) Pengembangan Teknologi Terbaru (PTT) apakah berpengaruh positif terhadap Pengendalian Mutu Terpadu Karyawan (PMTK). Penelitian ini menggunakan metode penelitian Survey dengan menggunakan pendekatan kuantitatif. Hasil penelitian didapatkan Tingkat Produktivitas Karyawan berpengaruh positif terhadap Pengendalian Mutu Terpadu Karyawan dengan koefisien standarized 0,072. Pelatihan Karyawan berpengaruh positif terhadap Pengendalian Mutu Terpadu Karyawan dengan koefisien standarized 0,164. Pengembangan Teknologi Terbaru berpengaruh positif terhadap Pengendalian Mutu Terpadu Karyawan dengan koefisien standarized 0,114.

Kata Kunci :Produktivitas, Pelatihan, Pengembangan Teknologi, Pengendalian Mutu Terpadu.

\section{PENDAHULUAN}

Kemajuan pendidikan, teknologi, informasi, dan peradaban mendorong masyarakat konsumen semakin selektif dan cenderung untuk mengkonsumsi barang atau jasa yang bermutu baik. Hal ini menciptakan persaingan yang ketat antar perusahaan serta mendorong karyawan bekerja efektif dan efisien. Dengan begitu, barang atau jasa yang dihasilkan bermutu tinggi sehingga mempunyai daya saing yang besar di pasaran.

Pengendalian mutu terpadu mempunyai komitmen yang berasal dari dalam perusahaan atau organisasi. sebagai sebuah proses yang terintegrasi dengan berfokus pada pelanggan dan pimpinan penerima manfaat, namun secara bersamaan mempunyai tujuan untuk melindungi dan meningkatkan kepuasan semua pemangku kepentingan serta menghasilkan nilai yang terbesar dengan biaya yang minimum melalui alat-aiat dan teknik yang terus berkembang (Samudi, 1994). Dalam memperjuangkan mutu, tujuan akhirnya hendak dicapai adalah terciptanya kepuasan konsumen secara penuh, artinya konsumen akanpuas karena mendapatkan produk yang paling sesuai dehgan harapan dan keinginannya, harga yang relatif murah, penyampaian produk yang cepat dan tepat, aman dalam. penggunaan dan tidak mengganggu pikiran bagi pemakai produk tersebut karena mengkonsumsi atau menggunak produk. Oleh sebab itu Pengendalian Mutu Terpadu membutuhkan partisipasi dari semua divisi dalam perusahaan, seperti divisi pemasaran,disain, pabrikasi. pemeriksaan, laboratorium dan pemeriksaan. Oleh sebab itulah harus tercipta adanya keterpaduan dari berbagai unsur yang ada dalam perusahaan (Puspandoyo et al. [5]).

Pendidikan dan pelatihan karyawan merupakan hal yang sangat penting dalam peningkatan mutu Surnber Daya Manusia (SDM), Pendidikan dan pelatihan yang bermutu yang bermutu merupakan harapan dan dambaan bagi masyarakat. Implementasi Manajemen Mutu Terpadu (MMT) bila diterapkan secara tepat dapat membantu meningkatkan kinerja suatu organisasi (Yusmina et. al. [9]). Program pengembangan karyawan hendaknya disusun secara cermat dan didasarkan kepada metode-metode ilmiah serta berpedoman pada keterampilan yang dibutuhkan perusahaan atau korporasi baik sekarang maupun dimasa yang akan datang. Pengembangan harus bertujuan untuk meningkatka kemampuan teknis, teoritis, konseptual dan moral karyawan supaya prestasi kerjanya baik dan mencapai hasil optimal (Budi et.al. [2]).

Pengembangan karyawan dirasa semakin penting manfaatnya karena tuntutan pekerjaan, sebagai akibat kemajuan teknologi dan semakin ketatnya persaingan di antara perusahaan yang sejenis. Setiap personel perusahaan dituntut agar dapat bekerja efektif, efisien, kualitas dan kuantitas pekerjaannya baik sehingga daya saing perusahaan semakin besar (Anggraeni et.al [1]). Pengembangan ini dilakukan untuk tujuan nonkarier maupun karier bagi para karyawan (baru atau lama) melalui latihan dan pendidikan. 
Pimpinan perusahaan harus menyadari bahwa karyawan baru pada umumnya hanya mempunyai kecakapan teoritis saja dari bangku kuliah. Jadi, perlu dikembangkan dalam kemampuan nyata untuk dapat menyelesaikan pekerjaannya. Pengembangan karyawan memang membutuhkan biaya cukup besar, tetapi biaya ini merupakan bidang personalia. Karena karyawan yang cakap dan trampil akan dapat bekerja lebih efisien, efektif, pemborosan bahan baku, dan ausnya mesin berkurang, hasil kerjanya lebih baik maka daya saing perusahaan akan semakin besar. Hal ini akan memberikan peluang yang lebih baik bagi perusahaan untuk memperoleh laba yang semakin besar sehingga balas jasa (gaji dan benefit) karyawan dapat di naikkan.

Di era globalisasi saat ini, sudah saatnya Indonesia memiliki paradigma baru tekno ekonomi (Techno-economy paradigm) untuk meningkatkan daya saing berkelanjutan. Paradigma ini menyakini bahwa teknologi sebagai kontibutor utama dalam peningkatan kualitas hidup bangsa. Paradigma ini membawa implikasi terjadinya pergeseran perekonomian dunia yang semula berbasis pada sumberdaya ekonomi (Resource based economy) menuju perekonomian yang lebih berbasis kepada ilmu pengetahuan (Knowledge based economy) dan teknologi (IPTEK) sebagai kunci utamanya.

Hasil riset (Prasetyo, 2016) menunjukkan bahwa pada industri Tektsil dan Produk Tekstil (TPT) yang tenaga kerjanya memiliki ketrampilan dan tingkat pendidikan yang cenderung lebih tinggi, kencenderungan karyawan untuk lebih kreatif dan dapat mengerjakan multifungsi pekerjaan yang ditawarkan kepada mereka. Para pekerja golongan ini juga lebih cepat menerima perubahan termasuk pemanfaatan pengunaan teknologi baru dalam pekerjaannya. Dari sisi teknologi, para pengusaha industri TPT umumnya belum melakukan perbaikan sistem dan teknik produksi agar lebih produktif dan mutunya bisa sama untuk setiap lembar kain yang diprduksi (Ulum, 2009).

Pelatihan dan pengembangan sumber daya manusia merupakan salah satu alat untuk menyesuaikan antara tugas dan pekerjaan dengan kemampuan, ketrampilan atau kecakapan dan keahlian dari setiap karyawan serta merupakan usaha untuk meningkatkan kinerja karyawan sebagai kegiatan pengenalan terhadap pekerjaan tertentu bagi yang bersangkutan. Baik tidaknya kinerja karyawan jelas akan mempengaruhi kestabilan sebuah organisasi dalam mencapai tujuan yang ditetapkan (Linarwati et.al.[3]).

Hasil penelitian yang dilakukan oleh (Rahmana et.al.[6]) yang dapat dirumuskan berdasarkan hasil penelitian adalah sebagai berikut: (1) pengembangan model pelatihan dirancang secara terintegrasi menggunakan pendekatan sisten (system approach) yang terdiri ataS komponen, yaiut: (a) raw input, (b) instrumental input, (b) environmental input, (c) process, (d) output, (e) other input, dan (f) outcomes, sehingga rancangan model tersebut tidak hanya berorientasi pada produk melainkan juga berorientasi pada konteks, konten, dan proses yang pada akhirnya akan bermuara kepada keajegan model tersebut dan (2) model pelatihan berbasis simulasi yang dikembangkan ternyata efektif dalam meningkatkan kompetensi daripada model pelatihan berbasis simulasi yang selama ini dilakukan (model konvensional).

\section{METODE PENELITIAN}

a. Waktu dan Lokasi Penelitian

Penelitian ini dilakukan di kawasan Solo raya, terdiri dari empat kabupaten (Kabupaten Sragen, Kabupaten Sukoharjo, Kabupaten Boyolali dan Kabupaten Karang Anyar), Jawa Tengahl. Penelitian dimulai pada bulan Januari 2017 sampai dengan bulan Juli 2017.

b. Metode Penelitian

Penelitian ini menggunakan metode penelitian Survey dengan menggunakan pendekatan kuantitatif. Teknik pengumpulan informasi yang dilakukan dengan cara menyusun daftar 
pertanyaan yang diajukan pada responden dalam berbentuk sampel dari sebuah populasi.

c. Pengumpulan dan Analisis Data

Pengumpulan data dilakukan dengan menyebarkan kuisioner pertanyaan item variabel yang berkaitan, secara rendom kepada 46 karyawan-karyawati di pabrik yang bergerak di bidang Tekstil dan Garmen di wilayah Solo Raya, Kabupaten Sukoharjo, PT. Sritek, 14 responden; Kabupaten Karang Anyar, PT. Kusuma Hadi, 10 responden; Kabupaten Boyolali, PT. Pan Brothers, 12 responden; dan Kabupaten Sragen, PT. Bati, 10 responden). Analisis data yang terkumpul kemudian di analisis dengan menggunakan teknik analisis regresi linier berganda, meggunakan softwere AMOS 22.0.

\section{HASIL DAN PEMBAHASAN}

Program AMOS dapat digunakan untuk menganalisa regresi berganda (Santoso, 2007; Bahri \& Zamzam, 2014), persamaan regresi dinyatakan kedalam persamaan seperti dibawah ini ;

$$
\mathrm{Y}=\alpha+\beta 1 \mathrm{X} 1+\boldsymbol{\beta} 2 \mathrm{X} 2+\boldsymbol{\beta} 3 \mathrm{X} 3+\varepsilon
$$

Persamaan regresi diatas digunakan untuk menggambarkan hubungan (endogen) Y dan variabel-variabel independen (exsogen) atau sering juga disebut predictor X1,X2 dan X3. Analisis regresi dengan Sequal Equation Modelling (SEM), menggunakan Softwere AMOS 22.0, digunakan untuk menganalisa data yang berasal dari 46 responden yang telah diambil datanya dengan kuisioner terdiri dari empat variabel pengamatan. Variabel yang akan diamati adalah ; Tingkat Produktivitas Karyawan (TPK), Pengembangan Teknologi Terbaru (PTT), Pelatihan Karyawan (PK), dan Pengendalian Mutu Terpadu Karyawan (PMTK).

$$
\begin{gathered}
\text { Mutu Karyawan }=\alpha+\beta 1 . \text { Produktivitas }+\beta 2 \\
\text { Pelatihan }+\beta 3 . \text { Teknologi }
\end{gathered}
$$

Menggambarkan model persarnaan regresi dalam program AMOS 22.0 seperti gambar 1 dibawah ini.

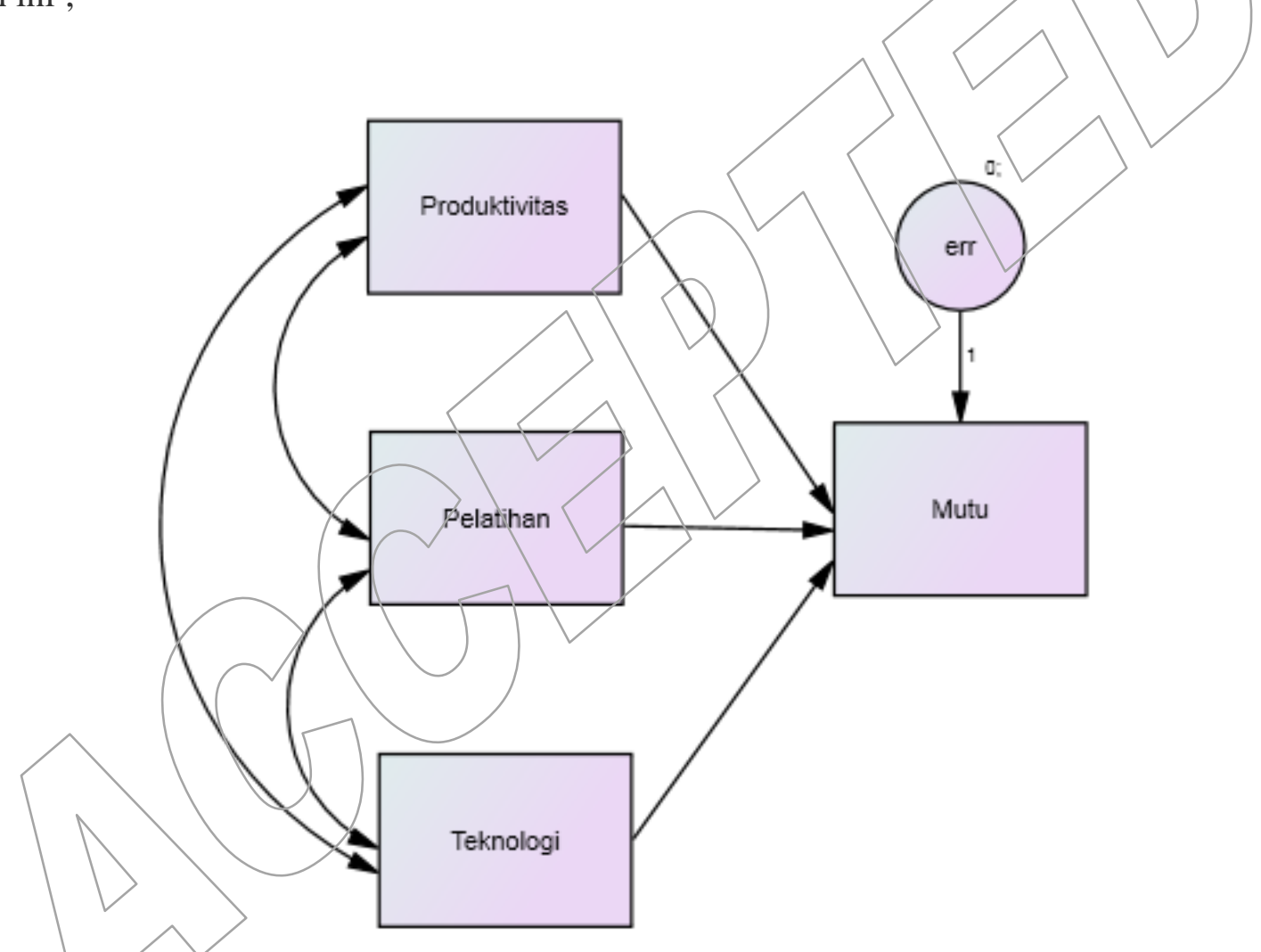

Gambar 1. Model Persamaan Regresi 
Gambar 1 menyatakan hubungan antar variabel-variabel yang akan di analisa dimana; (a) variabel Tingkat Produktivitas Karyawan (TPK) berpengaruh positif terhadap Pengendalian Mutu Terpadu Karyawan (PMTK); (b) Pelatihan Karyawan (PK) berpengaruh positif terhadap Pengendalian Mutu Terpadu Karyawan (PMTK); dan (c) Pengembangan Teknologi Terbaru (PTT) berpengaruh positif terhadap Pengendalian Mutu Terpadu Karyawan (PMTK).
Sampel yang digunakan dalam analisis penelitian ini kemudian dioleh datanya dengan menggunakan sofwere AMOSS 22, untuk menentukan metode estimasi dan output analisisnya. Motede estimasi yang digunakan adalah Maximum Likelihood (ML) dengan Estimasi Means and Intercept sehingga output yang diharapkan dapat dilihat pada gambar dan tebel output secara detail dibawah ini :

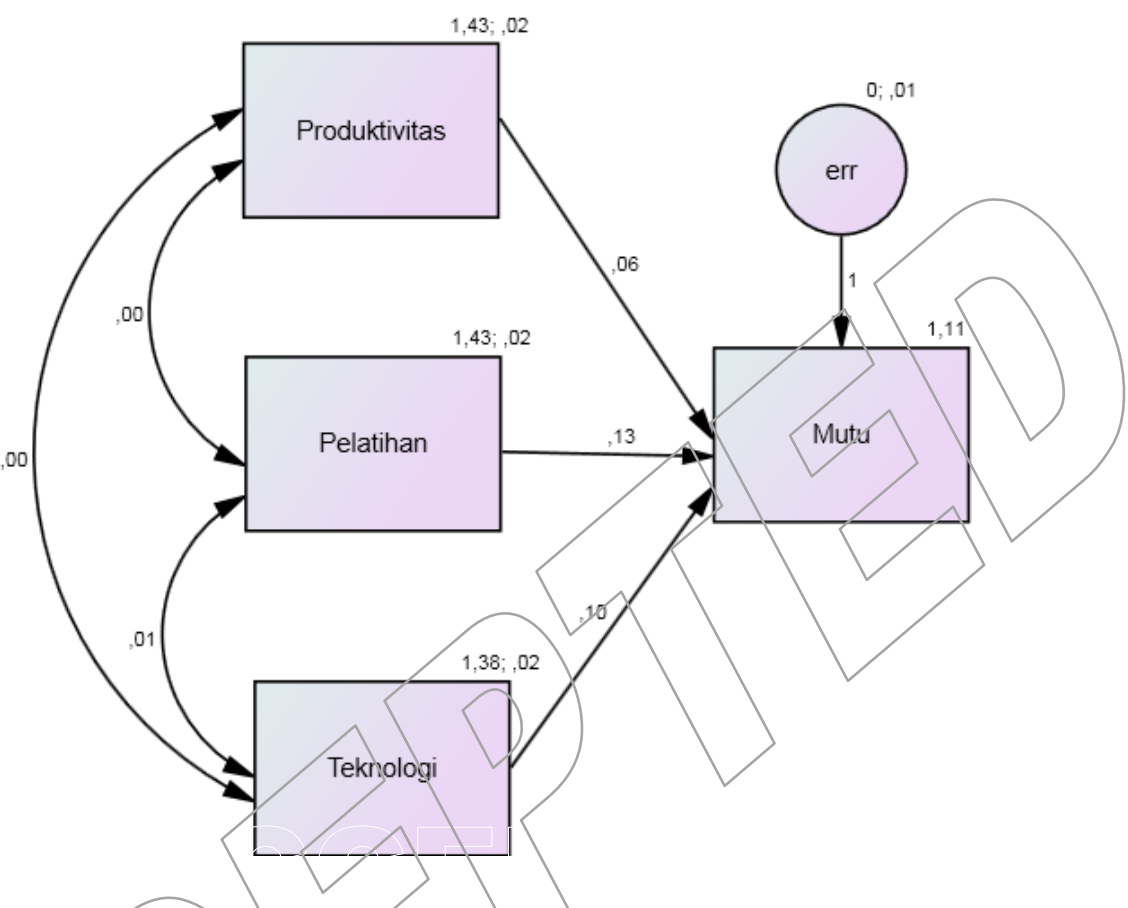

Gambar 2. Tampilan Hasil Analisis Regersi AMOS 22.0

Angka-angka yang muncul pada Gambar 2. Mengacu pada output Standarized Estimates dan Squared Multiple Correlation pada umumnya, menunjukkan bahwa semua indikator pada variabel-variabel memang berhubungan secara nyata dan memiliki pengaruh. 


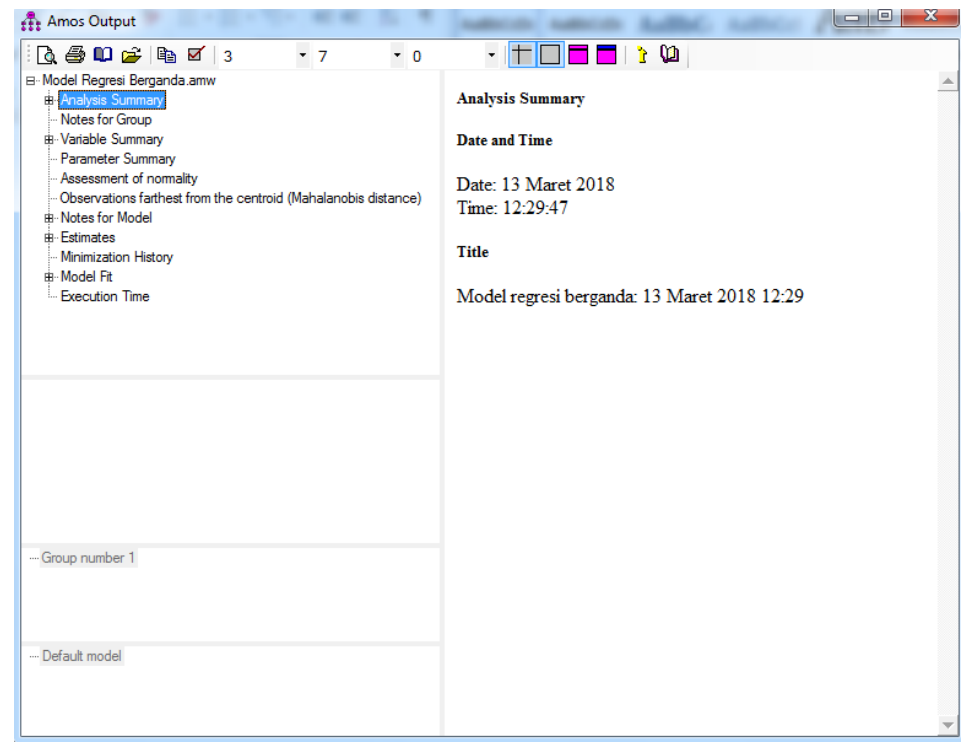

Gambar 3. Analysis summary

Analysis summary pada Gambar 3, berisikan keterangan tentang tanggal dan waktu data diolah serta nama file. Pada keluran output AMOSS 22 dapat penulis jelaskan bahwa data diolah kembali pada tanggal 13 Maret 2018, waktu pengolahan secara rinci dilakukan pada pukul 12:29:47, dimana file yang digunakan untuk pengolahan data adalah model regresi berganda.

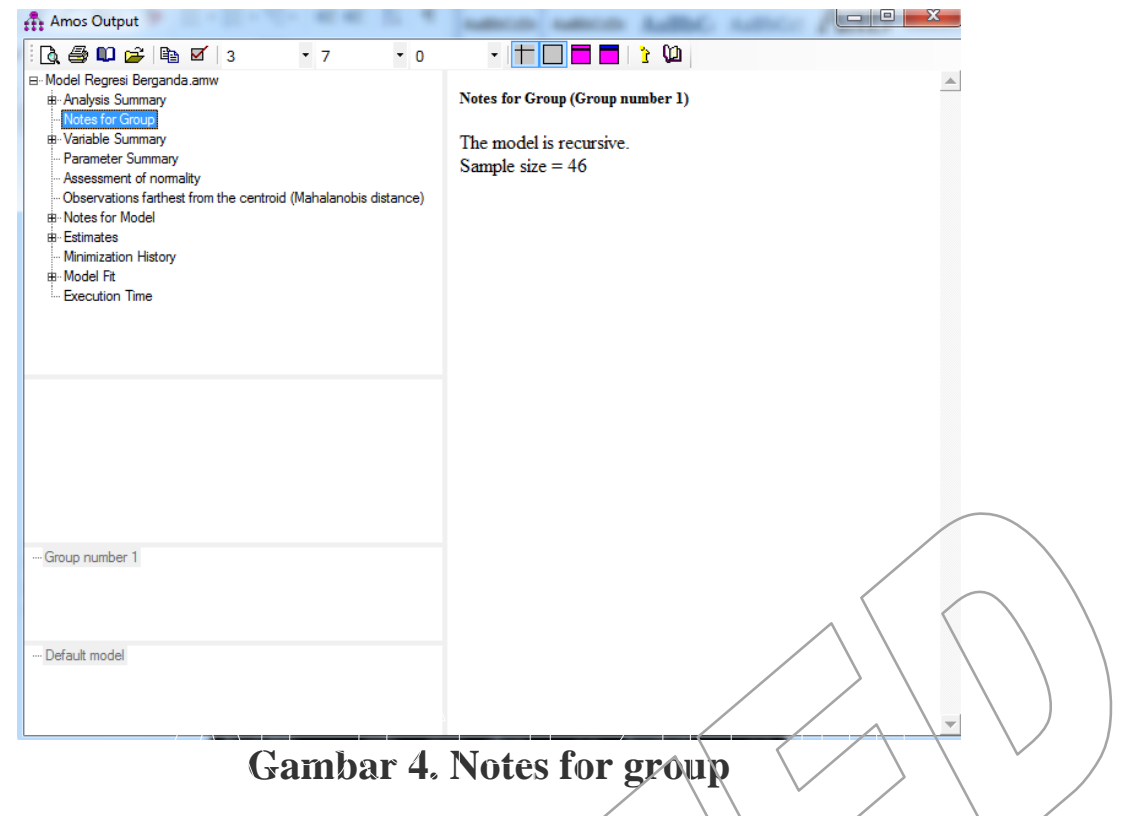

Notes for group pada gambar 4, berisikan keterangan bahwa model berbentuk recursive dimana model hanya terdiri dari satu arah dan bukan merupakan model resiprokal atau saling mempengaruhi (nonrecursive). Jumlah sampel yang digunakan dalam penelitian ini sebanyak 46 . 


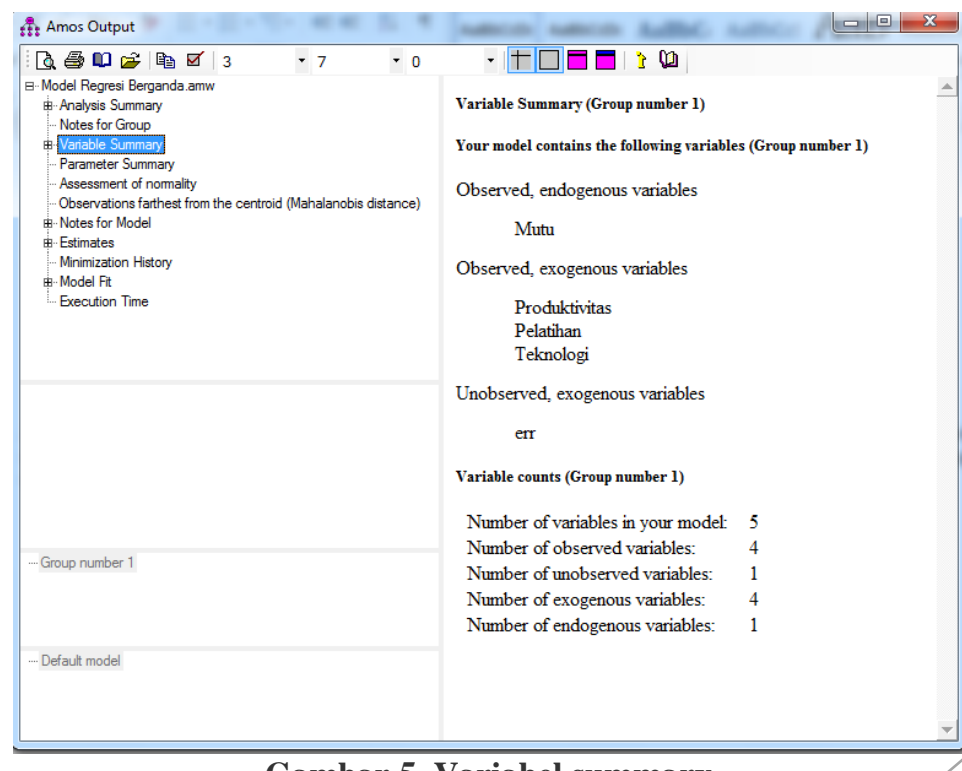

Gambar 5. Variabel summary

Variabel summary pada Gambar 5, berisi keterangan model memiliki satu variabel endogen yaitu Mutu dan tiga variabel exogen yaitu Produktivitas, Pelatihan dan Teknologi serta satu variabel unobserved exogen yaitu err. Jumlah variabel dalam model lirna yang terdiri dari empat yariabel observed dan satu variabel unoserved dan empat variabel exogen dan satu variabel endogen.

Tabel 1. Assessment of normality

\begin{tabular}{|lrrrrrrr|}
\hline Variable & min & may & skew & c.r. & kurtosis & c.r. \\
\hline Teknologi & 1,099 & 1,609 &,- 549 & $-1,496$ &, 941 & 1,302 \\
\hline Pelatihan & 1,099 & 1,609 &,- 479 & $-1,326$ &, 237 &, 328 \\
\hline Produktivitas & 1,599 & 1,609 &,- 479 & $-1,326$ &, 237 &, 328 \\
\hline Mutu & 1,386 & 1,609 &,- 087 &,- 241 & $-1,992$ & $-2,758$ \\
\hline Multivariate & & & & &,- 173 &,- 084 \\
\hline
\end{tabular}

Dengan tingkat kepercayaan 99\%. Pada tingkat kepercayaan tersebut, tingkat signifikansi adatah 100\%-99\%=1\%, dan angka $\mathrm{Z}$ adalah $\pm 2,58$. Dengan demikian, sebuah distribusi dikatakan normal jika angka cr skewness atau angka cr kurtois ada diantara $-2,58$ sampai $+2,58$. Jika dylihat dari (Tabel 1) terlihat secara Keseluruhan multivriat terdistribusi secara normal, karena angka multivariate $(-0,173)<2,58$. Demikian pula pada variabel Teknologi, Pelatihan, Produktivitas dan Mutu yang jauh dari batas $\pm 2,58$. Sehingga dapat disimpulkan bahwa data yang digunakan dalam penelitian ini adalah normal secara multivariate. Dengan demikian data yang digukan bisa memenuhi persyaratan untuk dilakukan analisis data lebih lanjut dan hasil analisis keluaran bisa digunakan sebagai kesimpulan hubungan masing-masing variabel yang di uji.

Tabel 2. Mahalanobis distance

\begin{tabular}{|c|c|c|c|}
\hline Observation number & Mahalanobis d-squared & p1 & p2 \\
\hline 1 & 9,645 &, 047 &, 890 \\
\hline 24 & 9,645 &, 047 &, 641 \\
\hline 20 & 8,374 &, 079 &, 713 \\
\hline
\end{tabular}




\begin{tabular}{|c|c|c|c|}
\hline Observation number & Mahalanobis d-squared & p1 & p2 \\
\hline 43 & 8,374 & 079 &, 496 \\
\hline 4 & 8,355 & 079 &, 301 \\
\hline 27 & 8,355 & 079 &, 155 \\
\hline 22 & 7,852 & ,097 &, 155 \\
\hline 45 & 7,852 & ,097 &, 074 \\
\hline 15 & 7,066 &, 132 &, 147 \\
\hline 38 & 7,066 & , 132 & 075 \\
\hline 8 & 5,776 & ,216 & ,410 \\
\hline 31 & 5,776 & ,216 & ,283 \\
\hline 10 & 5,038 & ,283 &, 560 \\
\hline 33 & 5,038 & ,283 &, 431 \\
\hline 16 & 4,477 &, 345 & ,661 \\
\hline 17 & 4,477 & ,345 &, 541 \\
\hline 39 & 4,477 & ,345 & ,418 \\
\hline 40 & 4,477 & ,345 &, 304 \\
\hline 14 & 4,062 & ,398 &, 471 \\
\hline 37 & 4,062 & ,398 &, 355 \\
\hline 9 & 3,341 &, 503 &, 780 \\
\hline 19 & 3,341 &, 503 &, $683 V$ \\
\hline 32 & 3,341 &, 503 &, 572 \\
\hline 42 & 3,341 & 503 &, 455 \\
\hline 7 & 2,863 &, $581 V$ &, 748 \\
\hline 18 & 2,863 &, 581 &, 646 \\
\hline 21 & 2,863 &, 581 &, 530 \\
\hline 30 & 2,863 & 581 &, 412 \\
\hline 41 & 2,863 &, 581 &, 301 \\
\hline 44 & 2,863 &, 581 & ,205 \\
\hline 3 & 2,342 &, 673 &, 565 \\
\hline 26 & 2,342 & 673 &, 440 \\
\hline 2 & 1,360 &, 851 & ,994 \\
\hline 11 & 1,360 &, 851 & ,986 \\
\hline 13 & 1,360 &, 851 & ,966 \\
\hline 23 & 1,360 &, 851 & ,929 \\
\hline 25 & 1,360 &, 851 &, 863 \\
\hline 34 & 1,360 & ,851 & ,761 \\
\hline 36 & 1,360 & ,851 & ,624 \\
\hline 46 & 1,360 &, 851 &, 462 \\
\hline 5 & 1,275 & ,866 &, 403 \\
\hline 6 & 1,275 & ,866 & ,241 \\
\hline 12 & 1,275 & ,866 & ,117 \\
\hline 28 & 1,275 &, 866 &, 043 \\
\hline 29 & 1,275 &, 866 &, 011 \\
\hline 35 & 1,275 &, 866 &, 001 \\
\hline
\end{tabular}

Mahalanobis distence pada Tebel 2 untuk mengukur apakah data memiliki outlier yaitu mendeteksi apakah skor observasi ada yang jauh berbeda dengan skor centroid untuk 46 
kasus. Mahalanobis $d$-squared digunakan untuk mengukur jarak skor hasil observasi terhadap nilai centroidnya. Pada kasus penelitian dengan data ini, dari outputnya tidak terdapat data yang dianggap outlier, sehingga semua data bisa dianalisa.

Tabel 3. Regression Weights

\begin{tabular}{|lccccccc|}
\hline Mutu & $<---$ & Produktivitas &, 056 &, 115 &, 490 &, 624 & \\
\hline Mutu & $<---$ & Pelatihan &, 128 &, 121 & 1,053 &, 293 & \\
\hline Mutu & $<---$ & Teknologi &, 097 &, 131 &, 740 &, 459 & \\
\hline
\end{tabular}

Regression weight memberikan besarnya nilai koefisien regresi undstandarized dan standarized. Nilai standarized $=$ nilai unstandarized - dengan standar error.

Tabel 4. Standarized Regression

\begin{tabular}{|c|c|c|c|}
\hline & & & Estimate \\
\hline Mutu & $<--$ & Produktivitas &, 072 \\
\hline Mutu & $\begin{array}{l}<-- \\
\end{array}$ & Pelatihan &,$\overline{164}$ \\
\hline Mutu & $\begin{array}{l}<-- \\
\end{array}$ & Teknologi &, 114 \\
\hline
\end{tabular}

Tabel 4 memberikan kesimpulan bahwa (a) produktivitas (Tingkat Produktivitas Karyawan) berpengaruh positif terhadap mutu (Pengendalian Mutu Terpadu Karyawan) dengan koefisien standarized 0,072, (b) Pelatihan (Pelatihan Karyawan) berpengaruh positif terhadap mutu (Pengendalian Mutu
Terpadu Karyawan) dengan koefisien standarized 0,164, dan (c) Teknologi (Pengembangan Teknologi Terbaru) berpengaruh positif terhadap mutu (Pengendalian Mutu Terpadu Karyawan) dengan koefisien standarized 0,114.

Tabel 5. Means

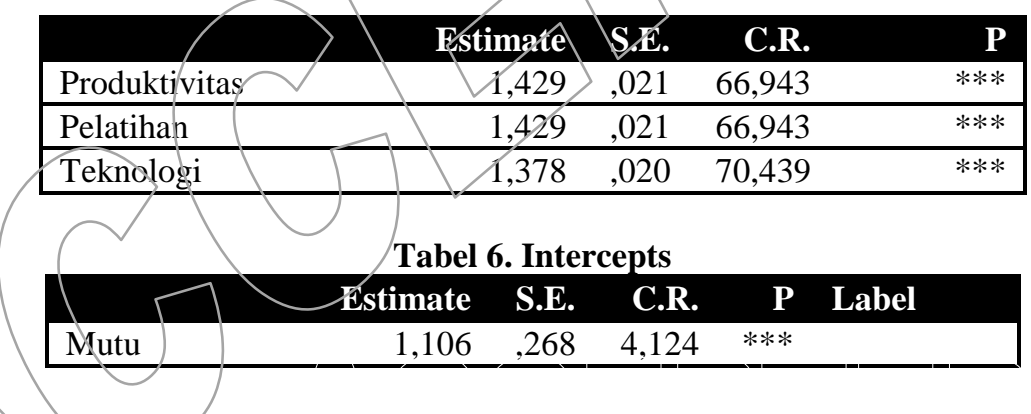

Output pada Means Tabel 5 dan Intercepts Tabel 6 mernberikan nilai means dan intercepts dari mơdel dengan nilai intercepts
1,106. Sehingga model persamaan regresi dapat dinyatakan pada persamaan (3).

Tabel 7. Squared Multiple Correlations

\begin{tabular}{|lr|}
\hline & Estimate \\
\hline Mutu &, 055 \\
\hline
\end{tabular}

Besarnya nilai koefisien determinasi ditunjukkan oleh nilai Squared Multiple Correlations $0,055\left(\mathrm{R}^{2}\right)$ yang berarti variabel Mutu yang dapat dijelaskan oleh variabel
Produktivitas, Pelatihan, dan Teknologi sebesar 5,5\%, sedangkan $85,5 \%$ adalah variabel lainnya yang tidak diteliti oleh penulis. 
Koefisien determinasi $\left(\mathrm{R}^{2}\right)$ pada intinya mengukur seberapa jauh kemampuan model dalam menerangkan variasi variabel dependen. Nilai koefisien determinasi adalah antara nol dan satu. Nilai $\mathrm{R}^{2}$ yang kecil berarti kemampuan variabel-variabel independen dalam menjelaskan variasi variabel dependen amat terbatas. Nilai yang mendekati satu berarti variabel-variabel independen memberikan hampir semua informasi yang dibutuhkan untuk memprediksi variasi variabel dependen. Secara umum koefisien determinasi untuk data silang (cross section) relatif rendah karena adanya variasi yang besar antara masing-masing pengamatan, sedangkan untuk data runtun waktu (time series) biasanya mempunyai nilai koefisien determinasi yang tinggi.

Kelemahan mendasar penggunaan koefisien determinasi adalah bias terhadap jumlah variabel independen yang dimasukkan ke dalam model. Setiap tambahan satu variabel independen, maka $\mathrm{R}^{2}$ pasti meningkat tidak peduli apakah variabel tersebut berpengaruh secara signifikan terhadap variabel dependen. Oleh karena itu banyak peneliti menganjurkan untuk menggunakan nilai adjusted $\mathrm{R}^{2}$ pada saat mengevaluasi mana model regresi terbaik. Tidak seperti $\mathrm{R}^{2}$, nilai adjusted $\mathrm{R}^{2}$ dapat naik atau turun apabila satu variabel independen ditambahkan ke dalam model. Dalam kenyataan nilai adjusted $\mathrm{R}^{2}$ dapat bernilai negatif, walaupun yang dikehendaki harus bernilai positif. Menurut Gujarati (2003) jika dalam uji empiris didapat nilai adjusted $\mathrm{R}^{2}$ negatif, maka nilai adjusted $\mathrm{R}^{2}$ dianggap bernilai nol.

Dalam artikel yang ditulis ini menggunakan metode statistik softwere aplikasi Structural Equation Modelling (SEM) dengan aplikasi AMOS 22. dimana mensyaratkan data terdistrubusi secara normal, jika data berdistribusi sangat tidak normal (non normal), maka hasil analisis dikhawatirkan menjadi bias. demikian pula jika ada sejumlah data outlier, yakni data mempunyai nilai jauh diatas atau di bawah rata-rata. dalam artikel bisa diperlihatkan bahwa hal tersebut tidak terjadi dimana data yang di tampilkan ketika di analisa dengan AMOSS didapatkan bahwa data terdistribusi normal dan layak untuk di ujikan selanjutnya. berkaitan dengan hasil $\mathrm{R}$ square yang kecil bahwa penelitian ini tidak salah karena variabel yang di ajukan dalam penelitian ini hanya untuk mengetahui apakah adanya hubungan atau korelasi. nilai yang kecil tidak mesti menyatakan penelitian ini kurang kridibel dan inilah merupakan temuan dari peneliti. "

Jadi dapat kita simpulkan bahwa model Pengaruh Peningkatan Produktivitas, Penguasaan Teknologi Baru dan Pelatihan Pada Industri Tekstil dan Garmen di Surakarta Terhadap Pengendalian Mutu Terpadu Karyawan memenuhi persamaan (4), dengan persamaan regresi menjadi ;

Mutu Karyawan $=1,106+0,056$ Produktivitas + 0,128 Pelatiban + 0,097 Teknologi

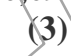

\section{KESIMPULAN}

a. Produktivitas (Tingkat Produktivitas Karyawan) berpengaruh positif terhadap mutu (Pengendalian Mutu Terpadu Karyawan), sehingga penerapan pengendalian mutu terpadu akan mengurangi jumlah kerusakan produk akhir serta down-time produksi, bagi karyawan yang memiliki tingkat produktivitas yang baik/tinggi secara terus-menerus merupakan langkah yang baik bagi korporasi terutama bagian produksi sebelum melepas produknya ke pasar.

b. Pelatihan (Pelatihan Karyawan) berpengaruh positif terhadap mutu (Pengendalian Mutu Terpadu Karyawan), Pendidikan dan latihan bagi karyawan akan menambah pengetahuan, pengalaman dan meningkatkan keterampilan kerja (skill) 
akan berdampak langsung terhadap produktivitas karyawan, dengan bertambahnya pengetahuan dan kemampuan karyawan akan mampu menentukan standar mutu yang dipersyaratkan dan sistem manajemen mutu terpadu.

c. Teknologi (Pengembangan Teknologi Terbaru) berpengaruh positif terhadap mutu (Pengendalian Mutu Terpadu Karyawan), Penerapan suatu teknologi dalam pengendalian mutu terpadu, akan memberikan perubahan besar-besaran dalam interaksi berproduktivitas bagi karyawan, dengan teknologi baru standar mutu yang menjadi target utama mudah bagi korporasi untuk mecapai target.

d. Penguasaan Teknologi Baru dan Pelatihan Pada Industri Tekstil dan Garmen di Surakarta Terhadap Pengendalian Mutu Terpadu Karyawan memenuhi persamaan ; Mutu Karyawan $=1,106+\mathbf{0 , 0 5 6}$ Produktivitas + 0,128 Pelatihan $+\mathbf{0 , 0 9 7}$ Teknologi

\section{DAFTAR PUSTAKA}

[1] Anggraeni, E. A., Herlambang, T., \& Nursaidah. (2016). Pengaruh Motivasi Kerja, Kompensasi Finansial Dan Kompensasi Non Finansial Terhadap Prestasi Kerja Karyawan Pada Perusahaan Bintang Mulia Hotel \& Resto Jember. Jurnal Manajemen Dan Bisnis Indonesia, 2(1), 1-15.

[2] Budi, A., Paramita, P., \& Wulan, H. (2016). Terhadap Komitmen Karyawan Yang Berdampak Pada Produktivitas Kerja ( Studi Kasus Karyawan Di Cv . Tirta. Journal Of Management, 2(2).

[3] Linarwati, M., Fathoni, A., \& Minarsih, M. (2016). Tudi Deskriptif Pelatihan Dan Pengembangan Sumberdaya Manusia Serta Penggunaan Metode Behavioral
Event Interview Dalam Merekrut Karyawan Baru Di Bank Mega Cabang Kudus. Journal Of Management, 2(2).

[4] Prasetyo, E. (2016). Dampak Kebijakan Peningkatan Techno-Economy Pada Industri Tekstil Sebagai Upaya Peningkatan Produktivitas Dan Daya Saing Bangsa. In Prosiding Seminar Nasional Multi Disiplin Ilmu \& Call For Papers Unisbank (Sendi_U) Ke-2 Tahun 2016 Kajian Multi Disiplin Ilmu Dalam Pengembangan Ipteks Untak Mewujudkan Pembangunan Nasional Semesta Berencan (Pnsb) Sebagai Upaya Meningkatkan Daya Saing Gi (Pp. 820 828). Semarang.

[5] Puspandoyo, T., Rohmawati, I., \& Wisiastuti, I. (2016). Total Quality Management Pada Unit Pelayanan Terpadu Penanggulangan Kemiskinan ( Uptkp ) Kabupaten Sragen. Aktual, 2(1), 34-42.

[6] Rahmana, A., Kamil, M., \& Sukaya, Y. (2016). Efektivitas Model Pelatihan Berbasis Simulasi Dalam Meningkatkan Kompetensi Manajemen Proyek Karyawan Industri Manufaktur. In Seminar Nasional Ienaco (Pp. 301-308).

[7] Samudi. (1994). Konsep Mutu Dalam Iso-9000 Dan. Economic Journal Of Emerging Markets, 5, 40-46.

[8] Ulum, I. (2009). Batik Dan Kontribusinya Terhadap Pereonomian Nasional. Jurnal Bestari Universitas Muhamadiyah Malang, 42(1), 21-32.

[9] Yusmina, E., Murniati, \& Niswanto. (2014). Dalam Peningkatan Kinerja Sekolah Pada Smk Negeri 1 Banda Aceh. Jurnal Administrasi Pendidikan Pascasarjana Universitas Syiah Kuala, 4(2), 168-178. 
[10] Santoso, Singgih. (2007). Structural Berbasis SEM-Amos. Deepublish: Equation Modelling: Konsep dan Yogyakarta. Aplikasi Dengan AMOS. Elex Media Komputindo. Jakarta.

[11] Bahri, Syamsul \& Zamzam, Fahkry. (2014). Model Penelitian Kuantitatif 